\title{
MANAJEMEN PENINGKATAN KUALITAS DOSEN (Studi Kasus pada Fakultas Tarbiyah UIN Malang)
}

\author{
S. Nor Hasanah Yasir \\ IAIN Pontianak, Indonesia \\ sayyidahnur81@yahoo.co.id
}

\begin{abstract}
This paper aims to uncover the management of improving the quality of Tarbiyah Faculty lecturers at UIN Malang about why and how universities conduct management to improve the quality of lecturers related to Tri Dharma. The method used in this study is a qualitative method with a case study approach of naturalistic inquiry. There are three dominant factors that influence the quality of the Tarbiyah Faculty lecturers at UIN Malang choosing the management of improving the quality of lecturers, namely internal factors, external factors, and the leader's excellence factors which then have divine, natural, human, scientific and global characteristics. The fundamental reason for the Tarbiyah Faculty of UIN Malang to choose management to improve the quality of lecturers is to realize the big ideals of making UIN Malang as the center of Islamic civilization with the power of solidity of faith, spiritual depth, majesty of knowledge, breadth of knowledge, and professional maturity.
\end{abstract}

Keywords: Management, Quality of Lecturers, UIN Malang

\begin{abstract}
Abstrak: Tulisan ini bertujuan untuk mengungkap manajemen peningkatan kualitas dosen Fakultas Tarbiyah UIN Malang tentang mengapa dan bagaimana PTIN melakukan manajemen peningkatan kualitas dosen terkait dengan Tri Dharma PTIN. Metode yang digunakan dalam penelitian ini ialah metode kualitatif denagn pendekatan studi kasus bersifat inquiry naturalistik. Ada tiga faktor dominan yang memengaruhi kualitas dosen Fakultas Tarbiyah UIN Malang memilih manajemen peningkatan kualitas dosen, yaitu faktor internal, faktor eksternal, dan faktor keunggulan pemimpin yang selanjutnya memiliki karakteristik ilahiyah, alamiah, insaniyah, ilmiah, serta global. Alasan mendasar Fakultas Tarbiyah UIN Malang memilih manajemen peningkatan kualitas dosen ialah ingin mewujudkan cita-cita besar yaitu menjadikan UIN Malang sebagai pusat peradaban Islam dengan kekuatan kekokohan aqidah, kedalaman spritual, keagungan ahlak, keluasan ilmu, dan kematangan profesional.
\end{abstract}

Kata Kunci: Manajemen, Kualitas Dosen, UIN Malang

\section{A. Pendahuluan}

Manajemen adalah suatu proses atau kerangka kerja yang melibatkan bimbingan atau pengarahan suatu kelompok orang ke arah tujuan organisasional atau maksud-maksud yang nyata. Pendapat lain mengatakan manajemen adalah suatu kegiatan, pelaksanaannya adalah "managing" 
pengelolaan, sedang pelaksanaanya disebut manager atau pengelola. ${ }^{167}$ Pendidikan tinggi merupakan suatu wadah untuk mencetak intelektual yang terampil, memiliki dedikasi yang tinggi, bisa menghadapi kemajuan Iptek dan Imtaq. Untuk menyiapkam mahasiswa atau mahasiswi yang lebih baik amat didorong oleh kesiapan dosen yang berkualitas. Kualitas Dosen merupakan hal yang penting. Hal itu dikarenakan, suatu perguruan tinggi tergantung pada kualitas dosenya. Kriteria ciri dosen yang berkualitas yang paling pokok adalah memiliki keahlian penguasaan bidang studi dan keahlian penguasaan metodologi. 168

Dosen yang berkualitas adalah dosen yang melaksanakan tanggung jawab pengajaran, bimbingan dan latihan keterampilan bagi mahasiswanya. G. Ryder berpendapat bahwa dosen dalam pelaksanaan pendidikan berkewajiban melaksanakan tugas mengajar dengan memakai perencanaan bahan kuliah, persiapan perkuliahan, hadir dikelas sesuai jadwal, mengemukakan syaratsyarat perkuliahan secara jelas, serta memberikan nilai secara objektif sesuai ketentuan lembaga. 169

Dapat dinyatakan secara aksiomatik bahwa tidak ada organisasi yang bergerak dalam keadaan teresolasi. Artinya, tidak ada organisasi yang boleh mengambil sikap tidak perduli terhadap apa yang terjadi dalam lingkungan di mana ia bergerak. Salah satu konsekuensi logis dari kenyataan demikian ialah bahwa manajemen sumber daya manusiapun harus sangat peka terhadap berbagai perubahan yang terjadi sekitar organisasi karena perubahan yang terjadi itu akan menimbulkan berbagai jenis tantangan yang harus dihadapi dan diatasi dengan baik.

Untuk membangkitkan masyarakat Universitas Islam Negeri (UIN) Malang yang terdiri dari rektor, dekan, dosen, administrasi, dan mahasiswa memerlukan kesiapan, niat atau tekad yang kuat serta sikap kerjasama dari

\footnotetext{
${ }^{167}$ Giorge R.Terry Leslie W.Rue, Principles of Management,(Jakarta: Bumi Aksara,1992), hlm.1.

168 Sanusi Uwes, Manajemen Pengembangan Mutu Dosen, (Bandung: 1998), hlm. 29.

169 Ryder, kenneth G. Faculty Raight And Responnsibility San Fransisco, (Washington: Jossey, 1970) hlm. 6.
} 
semua pihak yang dipelopori oleh rektor dan didukung oleh para dosen untuk berpartisipasi dalam melakukan pengelolaan pendidikan agama Islam untuk menghadapi masa depan yang lebih baik. Oleh karena itu, sesuai dengan tuntutan masyarakat dan berkembangnya peraturan baru maka dari itu formula baru pengelolaan Lembaga Pendidikan Islam ini harus ditingkatkan baik secara kuatitas maupun kualitas.

Ada dua orientasi penyelenggara pendidikan Islam. Pertama, pendidikan agama dilaksankan untuk menjadikan peserta didik beragama dengan baik. Pendidikan semacam ini juga dilaksanakan disekolah-sekolah umum mulai tingkat dasar sampai perguruan tinggi. Kedua, pendidikan agama dimaksudkan selain mengantarkan peserta didik menjadi beragama dengan baik sekaligus juga diharapkan mereka menjadi agamawan. Adapun yang dimaksud agamawan adalah mampu menjadi pemimpin, pemikir, dan juga peneliti agama.

Terkait dengan hal ini, Imam Suprayogo berpendapat bahwa untuk meningkatkan lembaga pendidikan tinggi ini secara menyeluruh tidak sulit asalkan ada kemauan. Lembaga ini sudah memiliki sandaran yang kokoh, yaitu berstatus negeri. Telah memiliki gedung yang memadai, tenaga dosen dan juga dukungan masyarakat yang besar. Masyarakat masih mempercayainya dengan bukti bahwa setiap tahun UIN Malang tidak pernah ada yang kekurangan peminat. Bahkan beberapa di ataranya sampai menolak dalam jumlah yang besar.

Strategi yang harus ditempuh bukan sekedar merombak kurikulum yang ada, mengirim dosen untuk studi lanjut, menambah buku-buku perpustakan, dan yang lebih mendasar ialah mengembalikan ruh yang dahulu pernah dimiliki pada awal kelahiranya. Sehingga yang penting adalah secara bersamasama melakukan konsolidasi kembali. Perguruan tinggi Islam maju, berwibawa, memiliki nama besar dalam kawasan yang lebih luas, maka tidak ada jalan lain yang bisa ditempuh kecuali memberikan suasana yang kondusif hingga menjadikan para tenaga pengajarnya tertantang untuk melakukan 
aktivitas-aktivitas ilmiah, begitu pula para mahasiswanya, dan para dosen tidak boleh selalu absen di bidang penelitian, seminar, mengikuti konferensikonferensi ilmiah hingga dengan demikian namanya menjadi bisa disebut dalam peraturan kegiatan keilmuan, tidak saja tingkat regional, akan tetapi nasional bahkan internasional. ${ }^{170}$

Perumusan masalah yang hendak dikaji berangkat dari fokus penelitian yaitu pola Peningkatan kualitas dosen Fakultas Tarbiayah UIN Malang. Sebagaimana yang telah dijelaskan di atas bahwa manajemen peningkatan kualitas dosen Fakultas Tarbiyah UIN Malang adalah suatu yang sangat rumit hal itu terjadi karena berkaitan dengan manusia jadi bukan barang mati lebih susah mengatur manusia dari pada mahluk Allah yang lainya antara keinginan mencetak ahli agama (ulama) dan ahli Iptek: Secara makro maupun mikro masih adanya tarik ulur berbagai kepentingan antar golongan, secara makro, secara mikro atau intern dosen Fakultas Tarbiyah UIN Malang terjadi antara kelompok tradisional yang identik dengan NU (Nahdlatul Ulama), kelompok modernis yang identik dengan Muhammadiyah dan nasionalis muslim. Berdasarkan hasil observasi bahwa sebagian di antara dosen Fakultas Tarbiyah UIN Malang, mereka jarang membawa persiapan bahan ajar seperti buku, silabus, dan kebanyakan di antara mereka mengajar menoton tidak menggunakan media pembelajaran yang maksimal, duduk di singgasananya dan kurang memacu serta memotivasi mahasiswanya

Tinggi rendahnya kualitas dosen ditandai dengan unsur kreativitas dan produktivitas yang direalisasikan dengan hasil kerja baik secara perorangan atau kelompok. Permasalahan ini dapat di atasi apabila dosen mampu menampilkan hasil kerja produktif secara rasional dan memiliki pengetahuan, keteranpilan, dan kemampuan yang umumnya dapat diperoleh melalui pendidikan. Dengan demikian, pendidikan sebagai salah satu solusi untuk meningkatkan kualitas dosen yang ada di Fakultas Tarbiyah UIN Malang.

170 Suprayogo, Imam, Reformoasi Visi Pendidikan Islam, (Malang: STAIN Press, 1999), hlm. 7. 


\section{B. Pengertian Manajemen}

Pengertian manajemen sama halnya dengan administrasi, kata manajemen juga berasal dari Bahasa Latin, yaitu dari asal kata manus yang berarti tangan dan agere yang berarti melakukan. Kata-kata itu digabung menjadi kata kerja managere yang artinya menangani. Managere ditarjamahkan kedalam Bahasa Inggris dalam bentuk kata kerja to manage, dengan kata benda management, dan manager untuk orang yang melakukan manajemen. Akhirnya manajemen ditarjemahkan kedalam Bahasa Indonesia menjadi manajemen atau pengelolaan. ${ }^{171}$

Menurut Rohiat sebagaimana yang dikuti oleh Rochmat Koswara, manajemen adalah mengelola sumber daya yang dimiliki oleh sekolah atau organisasi yang diantaranya adalah manusia, uang, metode, dan material yang dilakukan secara sistematis meliputi perencanaan, pengorganisasian, pengarahan, dan pengendalian. Sedangkan menurut E. Mulyasa, manajemen adalah suatu ilmu yang mempelajari bagaimana menata sumber daya untuk mencapai tujuan yang telah ditetapkan secara produktif dan bagaimana menciptakan suasana yang baik bagi manusia yang turut serta di dalam mencapai tujuan yang disepakati bersama. Lebih lanjut dikemukakan bahwa penataan mengandung makna mengatur, memimpin, mengelola atau mengadministrasikan sumber daya yang meliputi perencanaan, pelaksanaan, pengawasan dan pembinaan. ${ }^{172}$

Manajemen dalam kamus Bahasa Indonesia adalah proses penggunaan sumber daya secara efektif untuk mencapai sasaran pimpinan yang bertanggung jawab atas jalanya suatu lembaga dan organisasi. ${ }^{173}$ Sedangkan peningkatan adalah proses perbuatan, cara meningkatkan, usaha, dan

${ }^{171}$ Husaini Usman, Manajemen Teori Praktik dan Reset Pendidikan, (Yogyakarta: Bumi Aksara, 2006), hlm. 3.

${ }^{172}$ Rochmat Koswara, “Manajemen Pelatihan Life Skill Dalam Upaya Pemberdayaan Santri Di Pondok Pesantren (Studi Deskriptif Kualitatif di Pondok Pesantren Misbahul Falah Desa Mandalasari Kecamatan Cikalongwetan Kabupaten Bandung Barat)," dalam Jurnal Empowerment, Volume 4, Nomor 1, Februari 2014, hlm. 42-43.

${ }^{5}$ Pusat Pembinaan dan Pengembangan Bahasa, Kamus Besar Bahasa Indonesia Edisi Kedua, (Jakarta: Depertemen Pendididkan Kebudayaan, 1991) hlm. 623. 
kegiatan. ${ }^{174}$ kualitas adalah tingkatan baik buruknya sesuatu, kadar, derajat atau taraf kepandaian, kecakapan mutu, sangat dibutuhkan tenaga terampil yang tinggi. ${ }^{175}$ Jadi manajemen peningkatan kualitas dosen adalah segala upaya yang dilakukan untuk menjadikan dosen yang berkualitas baik berkualitas dalam penulisan buku maupun kualitas dalam penelitian, dan pengabdian pada masyarakat.

Ijah Kurniawati176 mengutip pendapatnya Terry, ada lima fungsi manajemen itu sendiri, meliputi: planning (perencanaan), organizing (pengorganisasian), staffing (pengontrolan staf), motivating (mengarahkan), dan controlling (pengawasan). Oleh karena itu, prinsip manajemen pada dasarnya dirancang untuk suatu pernyataan dan ketentuan yang bersifat fundamental yang menjadi problem dalam mengambil tindakan-tindakan untuk menghadapi masalah tertentu. Prinsip manajemen sangat perlu diperhatikan dalam kegiatan sebuah lembaga, apalagi lembaga pendidikan seperti UIN Malang.

\section{Faktor-Faktor yang Mempengaruhi Peningkatan Kualitas Dosen}

Realita dosen merupakan faktor penting yang mencakup banyak faktor yang mempengaruhinya faktor tersebut terdiri dari faktor internal karyawan (personal/individu) atau para dosen dan faktor eksternal, yaitu kepemimpinan, sistem, tim, dan situsional. Faktor personal meliputi unsur pengetahuan, keterampilan (skill), kemampuan, kepercayaan diri, motivasi, dan komitmen yang dimilikki oleh tiap individu dosen. Faktor kepemimpinan meliputi aspek kualitas rektor atau dekan dan team leader dalam memberikan dorongan, semangat, arahan, dan dukungan kerja kepada dosen. Faktor tim meliputi kualitas dukungan dan semangat yang diberikan oleh rekan dalam satu tim, kepercayaan terhadap sesama aonggota tim, kelompok, dan keeratan anggota

${ }^{174}$ Ibid., hlm. 1060.

175 Ibid., hlm. 533.

${ }^{176}$ Ijah Kurniawati, "Manajemen Pesantren untuk Meningkatkan Keterampilan Berbicara Bahasa Arab di Pondok Pesantren Diniyyah Pasia Kabupaten Agam," dalam Jurnal al-Fikrah, Vol. IV, No. 2, Juli-Desember 2016, hlm. 171. 
tim dosen. Faktor sistem meliputi sistem kerja, fasilitas kerja dosen atau infrastruktur yang diberikan oleh Universitas.

Ada beberapa hal yang harus diperhatikan di antaranya adalah: Komitmen moralitas yang harus diperhatikan, sistem dan iklim. Harus ada kedisiplinan. Menghargai waktu kerja keras, sanksi dan reward juga harus ada, budaya dosen dan mahasiswa. Dosen harus berprestasi, termasuk peningkatan seni budaya. Mahasiswa tidak ngerumpi tapi menggalakkan diskusi. Perilaku sehari-hari sejalan dengan Islam: gaya berpakaian, jenis aktivitas dan sebagainya harus mengarah kepada amaliah Islam, jajaran pimpinan harus berorientasi kemanfaatan kepada masyarakat, menjadikan Perguruan Tinggi sebagai kumpulan para sarjana dan peneliti.

\section{Kendala-Kendala yang Dihadapi dalam Peningkatan Kualitas Dosen}

Perguruan tinggi berfungsi sebagai an agent of change, di negara-negara yang baru merdeka. Perguruan tinggi merupakan perpanjangan tangan pemerintah, dalam hal ini perguruan tinggi mengemban tugas pemerintah untuk mencerdaskan kehidupan bangsa. Kaitannya dalam hal ini adalah sebagus apapun dalam peningkatan kualiats dosen pasti ada yang namanya kendala-kendala yang dihadapinya.

Seorang pemimpin harus memainkan perananya dalam menyampaikan budaya akademik kepemimpinan yang mengedepanakan peningkatan profesinya, bersedia terlibat pada pengabdian masyarakat yang sesuai dengan disiplin ilmunya. Budaya akademik harus berkembang secara baik sesuai dengan perkembangan zaman selain itu budaya akademik akan tumbuh bila ada proses yang baik, namun sebagian dosen belum melaksanakan visi dan misi perguruan tinggi, masih ada dosen yang belum bersikap ilmiah baik dari penampilan maupun dari pemikiran.

Ada empat kreativitas yang dimiliki dosen UIN Malang salah satunya adalah: memiliki krativitas mengajar, kompetensi, dan peduli mahasiswa. Dari hal yang disebutkan di atas rata-rata belum tinggi, artinya belum terpenuhi 
keseluruhannya. Akan tetapi pihak kampus berusaha mengarahkan ke arah yang lebih baik. Jika dulunya tidak bagus bagaimana caranya harus meningkat dengan selalu diadakan pelatihan karya ilmiah, workshop, pelatihan melalui pengetahuan. Dalam peningkatan ini tidak harus pelatihan keluar, kampus akan mengadakan sendiri lalu kemudian mengundang pembicara dari luar. selain itu pihak kampus senantiasa selalu meningkatkan diri dan pelatihanpelatihan yang kemudian diolah sendiri, magang yang lebih dekat dengan profesi masing-masing dosen itu.

Selain itu, dosen mangajar hanya sebatas mengajar saja dan kurangnya perhatian terhadap mahasiswa. Hal itu diakibatkan banyakanya tugas yang dibebankan kepada dosen dan kurangnya komitmen dosen itu sendiri sehingga walaupun silabus itu sudah ada namun tidak berjalan sebagaimana mestinya. Faktor dalam kelemahan yang akan menjadi penghambat terutama dalam pengajaran, dosen lebih berorientasi pada administratif serta kurangnya komitmen walaupun silabus sudah ada tapi ini sebagian saja tidak semua dosen seperti itu kemudian kurang kompaknya ketika ada kegiatan yang berkaitan dengan peningkatan kualitas misalnya ketika ada wokshop dan lain sebagainya, mungkin mereka sibuk dengan urusanya masing-masing karena tugas dosen memang banyak sehingga tidak mungkin semua hadir.

Dalam pelaksanaan penelitian kendala yang relatif menghambat adalah SDM masing-masing dosen dan dana yang terbatas. Kemampuan penelitian yang belum memadai, akses ke sumber informasi masih kurang, belum tumbuhnya budaya meneliti maupun menulis karya ilmiah dan mempublikasinya, pemanfaatan hasil penelitian kurang sistematis, dan pada umumnya dosen mengajar di banyak tempat dan menekuni pekerjaan lain sehingga sering tidak dapat melaksanakan kegiatan penelitian apalagi dengan pelaksanaan pengabdian masyarakat sama sekali tidak mencerminkan masyarakat ilmiah.

Kegiatan pengabdian belum banyak membantu meningkatkan hidup masyarakat apalagi masyarakat pedesaan. Budaya akademik yang kurang baik 
akan tumbuh perilaku yang kurang baik pula di kalangan civitas akademik, maka sebaik apapun pembelajaran yang dikembangkan jika tidak ada sikap, perilaku yang mencerminkan, dan aturan yang mengikat terhadap dosen maka hal ini menyebabkan kualitas dosen menurun. Sebagai lembaga pendidikan UIN Malang sangat tergantung dengan kualitas dosennya maka dari itulah arah peningkatan kualitas dosen di Universitas Islam Negeri Malang ditujukan untuk meningkatkan kemantapan aqidah, kedalaman spritual, keluhuran akhlak, dan kompetensi di bidang ilmunya masing-masing.

\section{E. Pengaruh Efektivitas Mengajar Dosen}

Efektivitas mengajar dosen tentu berpengaruh terhadap tuntutan masyarakat akan kualitas lulusan perguruan tinggi sebagai produsen tenaga kerja dan tenaga ahli. Kualitas lulusan dari waktu ke waktu selalu berbeda dan cenderung semakin spesifik. Kualitas lulusan yang dicapai pada suatu saat boleh jadi akan tidak dibutuhkan di saat berikutnya, karena tuntutan pasar kerja akan kualitas lulusan terus berubah. Perguruan tinggi diharapkan dapat menghasilkan lulusan yang dapat berkarya secara mandiri dalam masyarakat dan memiliki pengetahuan, keterampilan, serta sikap untuk mampu berkompetensi secara luas.

Perbedaan pokok antara kurikulum lama dengan kurikulum yang akan diberlakukan antaralain bahwa pada kurikulum berbasis kompetensi fokus perhatian tidak lagi kepada materi yang ingin disampaikan tetapi lebih terfokus kepada proses dan hasil belajar. Pada kurikulum baru, belajar berarti menciptakan makna sebagai hasil interaksi mahasiswa dengan lingkungan belajar dan beragam sumber belajar, termasuk tenaga pengajar.

Apabila kurikulum tersebut berorientasi kepada proses, maka partisipasi mahasiswa harusnya lebih aktif baik ketika menerima informasi keilmuan, maupun ketika mereproduksi informasi keilmuan tersebut secara benar dan tepat sebagai hasil belajar. Selain itu, peran tenaga pengajar juga mengalami pergesaran dari hanya sekadar penyampai ilmu manjadi dirigen yang 
memimpin proses pembelajaran, menjadi fasilitator atau perancang pengalaman belajar. Sebagai seorang fasilitator, tenaga pengajar berperan memberi bantuan kepada mahasiswa untuk berkembang. Di sinilah letak pentingnya ketersediaan media berbasis luas, yaitu membantu kedua belah pihak mahasiswa dan tenaga pengajar. Media berbasis luas sangat diperlukan tidak hanya dapat dimanfaatkan sebagai alat bantu penyajian dan pengumpulan informasi, tetapi juga sebagai alat bantu untuk memproses, memproduksi dan mengomunikasikan hasil belajar mahasiswa.

Pada hakikatnya, proses belajar mengajar adalah proses komunikasi yang harus diciptakan atau diwujudkan melalui kegiatan penyampaian dan tukar menukar pesan atau informasi oleh setiap tenaga pengajar dan peserta didik. Pesan atau informasi dapat berupa pengetahuan, keahlian, skill, ide, pengalaman, dan sebagainya. Melalui proses komunikasi, pesan atau informasi dapat diserap dan dihayati orang lain. Agar tidak terjadi kesesatan atau ambiguitas dalam proses komunikasi perlu digunakan sarana yang membantu proses komunikasi yang disebut media.

Dalam proses belajar mengajar, media yang digunakan untuk memperlancar komunikasi belajar mengajar disebut Media Pembelajaran. Terkait dengan ini maka sesuai dengan data yang di dapat dari beberapa alumni Fakultas Tarbiyah UIN Malang yang sudah bekerja baik sebagai guru maupun paraktisi pendidikan dan alumni yang diterima di perguruan tinggi terkemuka di luar negeri, bahwa Fakultas Tarbiyah UIN Malang telah mampu menetapkan dan mewujudkan visinya serta telah mampu memenuhi kebutuhan stakeholders berupa kebutuhan masyarakat, kebutuhan dunia kerja dan kebutuhan profesional.

Fakultas Tarbiyah UIN Malang bisa hidup dan terus maju ditentukan oleh dukungan masyarakat pelanggan (orang tua, mahasiswa, dan stakeholder) dukungan pelanggan tersebut juga tergantung apakah kebutuhan dan keinginan dapat dipenuhi dan dipuaskan oleh Fakultas Tarbiyah UIN Malang. 


\section{F. Kesimpulan}

Sesuai dengan rumusan masalah maka dapat disimpulkan bahwa untuk meningkatkan Kualitas Dosen Fakultas Tarbiyah UIN Malang lebih memberikan prioritas pada kegiatan peningkatan kualitas dosen Fakultas Tarbiyah UIN Malang, menumbuhkan nilai-nilai keihlasan, kepercayaan yang telah diberikan pemerintah dan masyarakat, menjaga dan meningkatkan etos kerja yang berkualitas. Manajemen peningkatkan bimbingan dan kontrol dalam rangka lebih mengefektifkan fasilitas yang tersedia di Fakultas Tarbiyah UIN Malang, pemimpin juga perlu mengadakan kotrol, evaluasi secara terus menerus. Penelitian berorientasi kepada kebutuhan masyarakat dan yang dapat meningkatkan kualitas mahasiswa, yang memiliki profil lulusan "ulama yang intelek profesional dan atau intelek profesional yang ulama".

\section{DAFTAR PUSTAKA}

Bartol, Kathryn M. \& David C. Martin, Management, USA: McGraw-Hill Inc, 1994.

Chaterine, Marshall Gretchen dan B. Rossman, Designing Qualitative Research, London United: Kingdom, 1995.

Depertemen Pendididkan Kebudayaan, Kamus Besar Bahasa Indonesia, Jakarta. Pustaka Sinar Harapan, 1991.

Edward, Sallis, Total Quality managemen in Education, Jogjakarta: IRCiSoD, 2006. Koswara, Rochmat, "Manajemen Pelatihan Life Skill Dalam Upaya Pemberdayaan Santri Di Pondok Pesantren (Studi Deskriptif Kualitatif di Pondok Pesantren Misbahul Falah Desa Mandalasari Kecamatan Cikalongwetan Kabupaten Bandung Barat)," dalam Jurnal Empowerment, Volume 4, Nomor 1, 2014. (https:/ / doi.org/10.22460/empowerment.v3i1p37-50.571)

Kurniawati, Ijah, “Manajemen Pesantren untuk Meningkatkan Keterampilan Berbicara Bahasa Arab di Pondok Pesantren Diniyyah Pasia Kabupaten Agam," dalam Jurnal al-Fikrah, Vol. IV, No. 2, Juli-Desember 2016. 
JRTIE: Journal of Research and Thought of Islamic Education

Marbun, B.N., Konsep Manajemen Indonesia, Jakarta: PPM, 1980.

Pariata Westra, dkk., Ensiklopedi Administrasi, Jakarta: Gunung Agung, 1981.

Piper, D.W., Quality Management in Universities, Canberra: Australia Government Publishing Service, 1993.

Rue, Giorge R. Terry Leslie W., Principles of Management, Jakarta: Bumi Aksara, 1992.

Suharsimi Arikunto, Prosedur Penelitian Suatu Pendekatan Praktik, Jakarta: Rineka Cipta, 1996.

Suprayogo, Imam, Quo Vadis Pendidikan Islam, Malang: UIN-Malang Press, 2006.

Terry, George R., Prinsip-Prinsip Manajemen, Jakarta: Bumi Aksara, 1990.

Usman, Husaini., Manajemen Teori Praktik dan Riset Pendidikan, Manajemen Pengembangan Kurikulum, Yogyakarta: Bumi Aksara, 2006. 